\title{
Lycium barbarum polysaccharides protect human trophoblast HTR8/SVneo cells from hydrogen peroxide-induced oxidative stress and apoptosis
}

\author{
JING LI $^{1}$, ZHONGJUN DING $^{2}$, YUE YANG $^{3}$, BAOHONG MAO $^{1}$, YANXIA WANG $^{1}$ and XIAOYING XU ${ }^{4}$ \\ ${ }^{1}$ Department of Women and Children's Medical Center; ${ }^{2}$ Reproduction Medicine Center, Gansu Provincial Maternity and \\ Child Care Hospital, Lanzhou, Gansu 730050; ${ }^{3}$ Discipline of Physiology, Gansu University of Chinese Medicine, Lanzhou, \\ Gansu 730000; ${ }^{4}$ Perinatal Center, Gansu Provincial Maternity and Child Care Hospital, Lanzhou, Gansu 730050, P.R. China
}

Received October 11, 2017; Accepted April 13, 2018

DOI: $10.3892 / \mathrm{mmr} .2018 .9274$

\begin{abstract}
Pregnancy complications are associated with abnormal cytotrophoblast differentiation and invasion. Hydrogen peroxide $\left(\mathrm{H}_{2} \mathrm{O}_{2}\right)$ is an important mediator of oxidative ischemia/reperfusion stress in the placenta. Lycium barbarum polysaccharides (LBP) have been demonstrated to counteract oxidative free radicals. The effects of LBP in trophoblast HTR8/SVneo cells injured with $\mathrm{H}_{2} \mathrm{O}_{2}$ were examined. A cell counting kit- 8 assay was performed to detect the effect of LBP at different concentrations on the proliferative ability of $\mathrm{H}_{2} \mathrm{O}_{2}$ injured trophoblast cells. Flow cytometry was used to determine the levels of reactive oxygen species (ROS), mitochondria membrane potential (MMP) disruption and apoptosis. Superoxide dismutase (SOD) activity and lactate dehydrogenase (LDH) leakage into the supernatant was detected by ultraviolet spectrophotometry. Reverse transcription-quantitative polymerase chain reaction and western blot analysis were performed to detect the expression of apoptosis-associated factors, including survivin, hypoxia inducible factor 1- $\alpha$ (HIF1- $\alpha$ ), Bcl-2 apoptosis regulator (Bcl-2), Bcl-2 associated $\mathrm{X}$ apoptosis regulator (Bax). The results revealed that LBP protected the proliferative ability of trophoblast cells injured with $\mathrm{H}_{2} \mathrm{O}_{2}$ in a dose-dependent manner. LBP inhibited the oxidative stress induced by $\mathrm{H}_{2} \mathrm{O}_{2}$, by reducing ROS and LDH levels and increasing SOD activity. Additionally, LBP decreased MMP disruption and cell apoptosis induced by $\mathrm{H}_{2} \mathrm{O}_{2}$, by increasing the mRNA and protein expression of survivin, HIF1- $\alpha$ and Bcl-2 and decreasing Bax expression. Therefore, it was concluded that LBP protected
\end{abstract}

Correspondence to: Dr Xiaoying Xu, Perinatal Center, Gansu Provincial Maternity and Child Care Hospital, 143 North Street, Qilihe, Lanzhou, Gansu 730050, P.R. China

E-mail: xiaoyingxuou@163.com

Key words: Lycium barbarum polysaccharides, human trophoblast cells, HTR8/SVneo cells, hydrogen peroxide, oxidative stress, cell apoptosis human trophoblast cells from $\mathrm{H}_{2} \mathrm{O}_{2}$-induced oxidative stress and cell apoptosis via regulation of apoptosis-associated factor expression. It will provide a novel strategy for the treatment of pregnancy complications.

\section{Introduction}

Preeclampsia (PE), preterm labor and intrauterine growth retardation (IUGR) are detrimental pregnancy complications that result in significant perinatal morbidity and mortality. Normal placental development is associated with the differentiation and invasion of trophoblasts, the predominant cellular component of the placenta. PE is one of the most common and serious pregnancy complications characterized by maternal endothelial dysfunction (1). PE pathogenesis originates from abnormal cytotrophoblast differentiation, shallow cytotrophoblast invasion of the uterus and decreased maternal blood flow to the placenta (2). In addition, it is associated with future development of cardiovascular disease in the mother and child (3).

The molecular mechanism of PE remains unclear, but oxidative stress is considered to have an important role in the endothelial dysfunction and systemic vasoconstriction associated with PE $(4,5)$. Hydrogen peroxide $\left(\mathrm{H}_{2} \mathrm{O}_{2}\right)$, a key factor in the cellular oxidative stress cascade, is also reported as an important component in placental oxidative ischemia/reperfusion stress $(6,7)$. Previous study has demonstrated that more $\mathrm{H}_{2} \mathrm{O}_{2}$ is produced in the maternal circulation of patients with PE in the stage of early pregnancy (8).

Apoptosis is critical for normal placental development and removes superfluous or dysfunctional cells to maintain normal tissue functions. However, apoptosis also participates in the pathophysiology of pregnancy complications (9). In addition, apoptosis is important in maintaining maternal immune tolerance to the antigens expressed on trophoblasts $(10,11)$. Increased trophoblast apoptosis has been observed in pregnancy complications, including PE and IUGR (12-14), indicating that an alteration in trophoblast apoptosis may result in these diseases (15-17).

Lycium barbarum polysaccharides (LBP) is the active ingredient extracted from Lycium barbarum is, a plant species 
which produces the wolfberry and a traditional Chinese medicine, and has beneficial effects, particularly in the liver, kidney and eyes $(18,19)$. Recent reports have demonstrated that LBP effectively improves immune function, resists oxidative free radicals and protects the testes from high-temperature injury (20). In China, Lycium barbarum is often used to treat male and female infertility in conjunction with other medicines. However, whether LBP repairs $\mathrm{H}_{2} \mathrm{O}_{2}$-induced injury in trophoblast cells remains unknown.

In the present study, an oxidative injury model of trophoblast cells damaged by $\mathrm{H}_{2} \mathrm{O}_{2}$ was established in order to determine the protective effect of LBP on $\mathrm{H}_{2} \mathrm{O}_{2}$-induced injury in trophoblast cells, and whether thus is mediated via apoptosis pathway regulation. The results of the present study may provide a novel strategy for the treatment of pregnancy complications, including PE and IUGR.

\section{Materials and methods}

Cell culture and treatment. Human trophoblast HTR8/SVneo cells were obtained from the American Type Culture Collection (Manassas, VA, USA). Cells were cultured in Dulbecco's modified Eagle's Medium (DMEM)/F12 nutrient mixture (Hyclone; GE Healthcare Life Sciences, Logan, UT, USA) supplemented with $10 \%$ fetal bovine serum (FBS; Gibco; Thermo Fisher Scientific, Inc., Waltham, MA, USA) and $1 \%$ penicillin/streptomycin in a humidified incubator containing $5 \% \mathrm{CO}_{2}$ at $37^{\circ} \mathrm{C}$. Cells in the logarithmic growth phase were used in subsequent experimentation.

LBP is the main active component of the Chinese wolfberry (21). LBP was purchased from Qinghai General Health Bio-science Co., LLC (Xining, China) and the purity of LBP was $>50 \%$. HTR $8 / \mathrm{SV}$ neo cells were treated with different concentrations (100, 200 and $400 \mu \mathrm{g} / \mathrm{ml})$ of LBP dissolved in PBS for 6 h. $\mathrm{H}_{2} \mathrm{O}_{2}(250 \mu \mathrm{mol} / \mathrm{l}$; Sigma-Aldrich; Merck $\mathrm{KGaA}$, Darmstadt, Germany) was subsequently added to treat cells for $6 \mathrm{~h}$. There were five experimental groups in total: $\mathrm{LBP} 1+\mathrm{H}_{2} \mathrm{O}_{2}$ (cells treated with $100 \mu \mathrm{g} / \mathrm{ml} \mathrm{LBP}$ and $250 \mu \mathrm{mol} / 1 \mathrm{H}_{2} \mathrm{O}_{2}$ ), LBP2 $+\mathrm{H}_{2} \mathrm{O}_{2}$ (cells treated with $200 \mu \mathrm{g} / \mathrm{ml}$ LBP and $250 \mu \mathrm{mol} / 1 \mathrm{H}_{2} \mathrm{O}_{2}$ ), LBP3 $+\mathrm{H}_{2} \mathrm{O}_{2}$ (cells treated with $400 \mu \mathrm{g} / \mathrm{ml} \mathrm{LBP}$ and $250 \mu \mathrm{mol} / 1 \mathrm{H}_{2} \mathrm{O}_{2}$ ), $\mathrm{H}_{2} \mathrm{O}_{2}$ (cells treated with $250 \mu \mathrm{mol} / 1 \mathrm{H}_{2} \mathrm{O}_{2}$ ) and control (without treatment) (22-24).

Cell viability assay. $\mathrm{HTR} 8 / \mathrm{SVneo} \mathrm{cell} \mathrm{viability} \mathrm{was} \mathrm{determined}$ following treatment with LBP and $\mathrm{H}_{2} \mathrm{O}_{2}$, with Cell Counting kit-8 (CCK-8) assay (Beyotime Institute of Biotechnology, Haimen, China). Cells were treated with $250 \mu \mathrm{mol} / 1 \mathrm{H}_{2} \mathrm{O}_{2}$ for 1 , 4 and $6 \mathrm{~h}$. Briefly, following cells treatments, cells were seeded into a 96-well plate at an initial density of $5 \times 10^{3}$ cells/well and incubated in DMEM media with FBS for $24 \mathrm{~h}$ at $37^{\circ} \mathrm{C}$. Then cells were treated with $100 \mu 1250 \mu \mathrm{mol} / 1 \mathrm{H}_{2} \mathrm{O}_{2}$ for 1,4 and $6 \mathrm{~h}$. At total of $20 \mu \mathrm{lCCK}-8$ reagent was added in and incubated for $1 \mathrm{~h}$ in a $5 \% \mathrm{CO}_{2}$ incubator at $37^{\circ} \mathrm{C}$. Finally, the optical density values were acquired with a microplate reader at $450 \mathrm{~nm}$.

Reactive oxygen species (ROS) detection. $\mathrm{ROS}$ were detected in different groups (Control, $\mathrm{H}_{2} \mathrm{O}_{2}$, $\mathrm{LBP} 1+\mathrm{H}_{2} \mathrm{O}_{2}$, $\mathrm{LBP} 2+\mathrm{H}_{2} \mathrm{O}_{2}$, LBP3 $+\mathrm{H}_{2} \mathrm{O}_{2}$ ) with a 2',7'-dichlorofluorescin diacetate (DCFH-DA) assay (Beyotime Institute of Biotechnology). After $6 \mathrm{~h}$ of $250 \mu \mathrm{mol} / 1 \mathrm{H}_{2} \mathrm{O}_{2}$ treatment, cells, treated with different concentrations (100, 200 and $400 \mu \mathrm{g} / \mathrm{ml})$ of LBP for $6 \mathrm{~h}$, were seeded into wells of 6-well plate. DCFH-DA $(10 \mu \mathrm{mol} / \mathrm{l})$ was subsequently added into each well. After incubation for $20 \mathrm{~min}$ at $37^{\circ} \mathrm{C}$, cells were rinsed with PBS and analyzed by flow cytometry. ROS levels were analyzed by CellQuest software version 5.1 (BD Biosciences, Franklin Lakes, NJ, USA) and results were calculated relative to the control group.

Mitochondria membrane potential (MMP) detection. Alterations in the MMP of each group treated with LBP (100, 200 and $400 \mu \mathrm{g} / \mathrm{ml}$ ) for $6 \mathrm{~h}$ and $250 \mu \mathrm{mol} / 1 \mathrm{H}_{2} \mathrm{O}_{2}$ for another $6 \mathrm{~h}$ were determined by aJC-1 assay (Nanjing KeyGen Biotech Co., Ltd., Nanjing, China), using the cationic dye to detect potential-dependent accumulation in mitochondria. Briefly, $5 \times 10^{5}$ cells were collected and resuspended in $500 \mu 1$ PBS with JC-1 $(10 \mu \mathrm{mol} / 1)$ for $20 \mathrm{~min}$ at $37^{\circ} \mathrm{C}$. MMP alterations were reflected by a fluorescence emission shift from $550 \mathrm{~nm}$ (red) to $525 \mathrm{~nm}$ (green). Cells were analyzed by flow cytometry with Cell Quest software version 5.1 (BD Biosciences).

Apoptosis detection. The cell apoptosis proportion in each group treated with LBP $(100,200$ and $400 \mu \mathrm{g} / \mathrm{ml})$ for $6 \mathrm{~h}$ and $250 \mu \mathrm{mol} / 1 \mathrm{H}_{2} \mathrm{O}_{2}$ for another $6 \mathrm{~h}$ were determined by an Annexin-V/propidium iodide (PI) double-stain assay, according to the manufacturer's protocol (Roche Diagnostics, Indianapolis, IN, USA). Briefly, both floating and trypsinized adherent cells $\left(5 \times 10^{5}\right)$ of the five experimental groups were collected and resuspended in $500 \mu \mathrm{l}$ PBS containing $0.5 \mu \mathrm{g} / \mathrm{ml}$ Annexin-V-fluorescein isothiocyanate for $20 \mathrm{~min}$. Subsequently, $400 \mu \mathrm{l}$ PBS with $50 \mu \mathrm{g} / \mathrm{ml}$ PI was added to cells for $5 \mathrm{~min}$ at room temperature in the dark. The analysis of cell apoptosis rate was immediately conducted with a flow cytometer and CellQuest software version 5.1 (BD Biosciences).

Superoxide dismutase (SOD) and lactate dehydrogenase $(L D H)$ detection. The cell supernatant of each group was collected. The activity of the antioxidant enzyme SOD was determined using the total SOD assay kit with WST-8 (Beyotime Institute of Biotechnology) according to the manufacturer's protocol. During the reaction process of SOD detection, 2-iodophenyl-3-nitrophenyl tetrazolium chloride was catalyzed to formazin, which could be detected by a microplate reader. The activity of LDH was detected with a LDH assay kit (Beyotime Institute of Biotechnology), according to the manufacturer's protocol.

Reverse transcription-quantitative polymerase chain reaction (RT-qPCR). The mRNA expression levels of survivin, hypoxia inducible factor 1- $\alpha$ (HIF1- $\alpha$ ) and Bcl-2 apoptosis regulator (Bcl-2), $\mathrm{Bcl}-2$ associated $\mathrm{X}$ apoptosis regulator (Bax) in each group was measured by RT-qPCR. Total RNA was extracted from cells using an RNeasy kit, and $1 \mu \mathrm{g}$ RNA was reverse transcribed to cDNA using a Quantiscript Reverse Transcriptase kit (both Qiagen, Inc., Valencia, CA, USA), according to the manufacturer's protocol. PCR amplification was performed for $15 \mathrm{sec}$ at $95^{\circ} \mathrm{C}$, followed by 40 cycles of denaturation at $95^{\circ} \mathrm{C}$ for $15 \mathrm{sec}$ and annealing/extension at $60^{\circ} \mathrm{C}$ for $25 \mathrm{sec}$ in an ABI 7300 Thermocycler (Applied Biosystems; 
Table I. Primers used in the reverse transcription-quantitative polymerase chain reaction.

\begin{tabular}{lll}
\hline Name & Direction & \multicolumn{1}{c}{ Sequence $\left(5^{\prime}-3^{\prime}\right)$} \\
\hline GAPDH & Forward & Size (base pairs) \\
& Reverse & CCATCTTCCAGGAGCGAGAT \\
Survivin & Forward & TGCTGATGATCTTGAGGCTG \\
& Reverse & GGACCACCGCATCTCTACAT \\
HIF1- $\alpha$ & Forward & TTGGTTCCTTTGCATGGGG \\
& Reverse & CAGTCGACACAGCCTGGATA \\
Bax & Forward & CCACCTCTTTTGGCAAGCAT \\
& Reverse & AACATGGAGCTGCAGAGGAT \\
Bcl-2 & Forward & AACATGGAGCTGCAGAGGAT \\
& Reverse & TTCTTTGAGTTCGGTGGGGT \\
\end{tabular}

HIF1- $\alpha$, hypoxia inducible factor 1- $\alpha$; Bcl-2, Bcl-2 apoptosis regulator; Bax, Bcl-2 associated $\mathrm{X}$ apoptosis regulator.

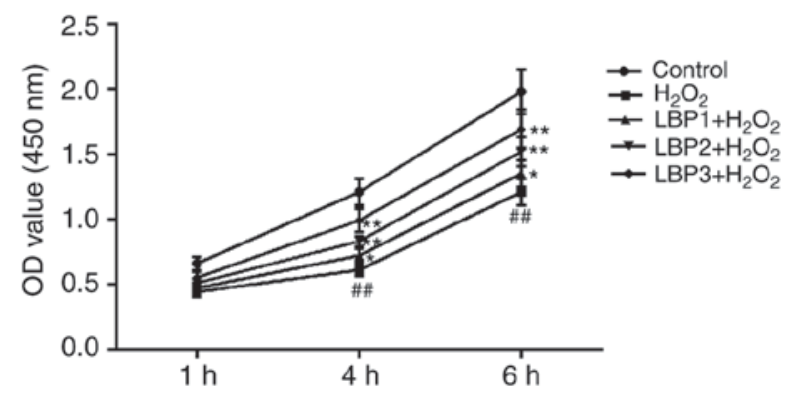

Figure 1. LBP protects the proliferative ability of HTR8/SVneo cells from $\mathrm{H}_{2} \mathrm{O}_{2}$ injury. A cell counting kit- 8 assay was conducted to detect cell proliferation in each group. ${ }^{\# \#} \mathrm{P}<0.01$ vs. control group; ${ }^{*} \mathrm{P}<0.05,{ }^{* *} \mathrm{P}<0.01$ vs. $\mathrm{H}_{2} \mathrm{O}_{2}$ group. OD, optical density; LBP, Lycium barbarum polysaccharide; $\mathrm{H}_{2} \mathrm{O}_{2}$, hydrogen peroxide.

Thermo Fisher Scientific, Inc.) with Fast SYBR-Green Master Mix (Applied Biosystems; Thermo Fisher Scientific, Inc.). GAPDH was used as the reference gene; primer sequences are displayed in Table I. The quantification was identified by $2^{-\Delta \Delta \mathrm{Cq}}$ method (25).

Western blot analysis. Cells were harvested, washed twice with PBS, lysed using lysis buffer (50 mM Tris-Cl, $150 \mathrm{mM}$ $\mathrm{NaCl}, 0.02 \% \mathrm{NaN} 2,100 \mu \mathrm{g} / \mathrm{ml}$ phenylmethanesulfonyl fluoride, $1 \mu \mathrm{g} / \mathrm{ml}$ aprotinin, and $1 \%$ Triton $\mathrm{X}-100)$ and centrifuged at a speed of $12,000 \mathrm{x}$ for $30 \mathrm{~min}$ at $4^{\circ} \mathrm{C}$. The supernatant was subsequently collected from the lysate and protein concentration was determined by a bicinchoninic acid protein assay (Beyotime Institute of Biotechnology). A total of $10 \mu \mathrm{g}$ proteins were boiled and separated by $10 \%$ SDS-PAGE, followed by transfer onto polyvinylidene fluoride (PVDF) membranes. Membranes were blocked with $5 \%$ non-fat dry milk in PBS for $1 \mathrm{~h}$ at $37^{\circ} \mathrm{C}$ and incubated with the following primary antibodies at $4^{\circ} \mathrm{C}$ overnight: Anti-survivin (cat. no. ab76424; 1:5,000), anti-HIF1- $\alpha$ (cat. no. ab51608; 1:1,000), anti-Bax (cat. no. ab53154; 1:1,000), anti-Bcl-2 (cat. no. ab59348; 1:1,000), anti-GAPDH (cat. no. ab9485; 1:2,500; all Abcam, Cambridge, MA, USA). Subsequently, proteins were incubated with horseradish peroxidase-conjugated goat anti-rabbit secondary antibody (cat. no. ab6721; 1:5,000; Abcam). PVDF membranes were exposed to X-ray film and immunoreactive bands were detected with an enhanced chemiluminescence detection kit (GE Healthcare Life Sciences). Finally, protein density was detected by Bio-Rad ChemiDoc XRS+ System with Image Lab Software version 4.1 (Bio-Rad Laboratories, Inc., Hercules, CA, USA).

Statistical analysis. Data is expressed as the mean \pm standard deviation of three independent experiments. Statistical analyses were performed using SPSS 18.0 (SPSS, Inc., Chicago, IL, USA) and significance was calculated with one-way analysis of variance followed by Dunnett's post hoc test. $\mathrm{P}<0.05$ was considered to indicate a statistically significant difference.

\section{Results}

LBP protects the proliferative ability of HTR8/SVneo cells injured with $\mathrm{H}_{2} \mathrm{O}_{2}$. To identify the effects of LBP on the proliferation of HTR8/SVneo cells injured by $\mathrm{H}_{2} \mathrm{O}_{2}$, a CCK8 assay was conducted in each experimental group (control, $\mathrm{H}_{2} \mathrm{O}_{2}, \mathrm{LBP} 1+\mathrm{H}_{2} \mathrm{O}_{2}, \mathrm{LBP} 2+\mathrm{H}_{2} \mathrm{O}_{2}$ and $\mathrm{LBP} 3+\mathrm{H}_{2} \mathrm{O}_{2}$ groups). The results revealed that the cell proliferation ability of the $\mathrm{H}_{2} \mathrm{O}_{2}$ group was significantly reduced by $250 \mu \mathrm{mol} / 1 \mathrm{H}_{2} \mathrm{O}_{2}$ in a time-dependent manner, compared with the control group $(\mathrm{P}<0.01)$. When pre-treated with LBP for $6 \mathrm{~h}$ prior to the addition of $\mathrm{H}_{2} \mathrm{O}_{2}$, proliferation in the $\mathrm{LBP} 1+\mathrm{H}_{2} \mathrm{O}_{2}$, $\mathrm{LBP} 2+\mathrm{H}_{2} \mathrm{O}_{2}$ and $\mathrm{LBP} 3+\mathrm{H}_{2} \mathrm{O}_{2}$ groups significantly increased in a dose-dependent manner, compared with the $\mathrm{H}_{2} \mathrm{O}_{2}$ group $(\mathrm{P}<0.05)$, indicating that LBP may protect the cell proliferation ability of HTR8/SVneo cells injured by $\mathrm{H}_{2} \mathrm{O}_{2}$ (Fig. 1).

$L B P$ reduces $R O S$ levels in HTR8/SVneo cells injured by $\mathrm{H}_{2} \mathrm{O}_{2}$. Intracellular ROS levels were measured using the oxygen-sensitive fluorescent dye DCTH-DA. The assay results revealed that the accumulation of ROS in HTR8/SVneo cells was significantly increased in the $\mathrm{H}_{2} \mathrm{O}_{2}$ group, compared with the control $(\mathrm{P}<0.01)$. Furthermore, a significant decrease in ROS formation was detected in 
A
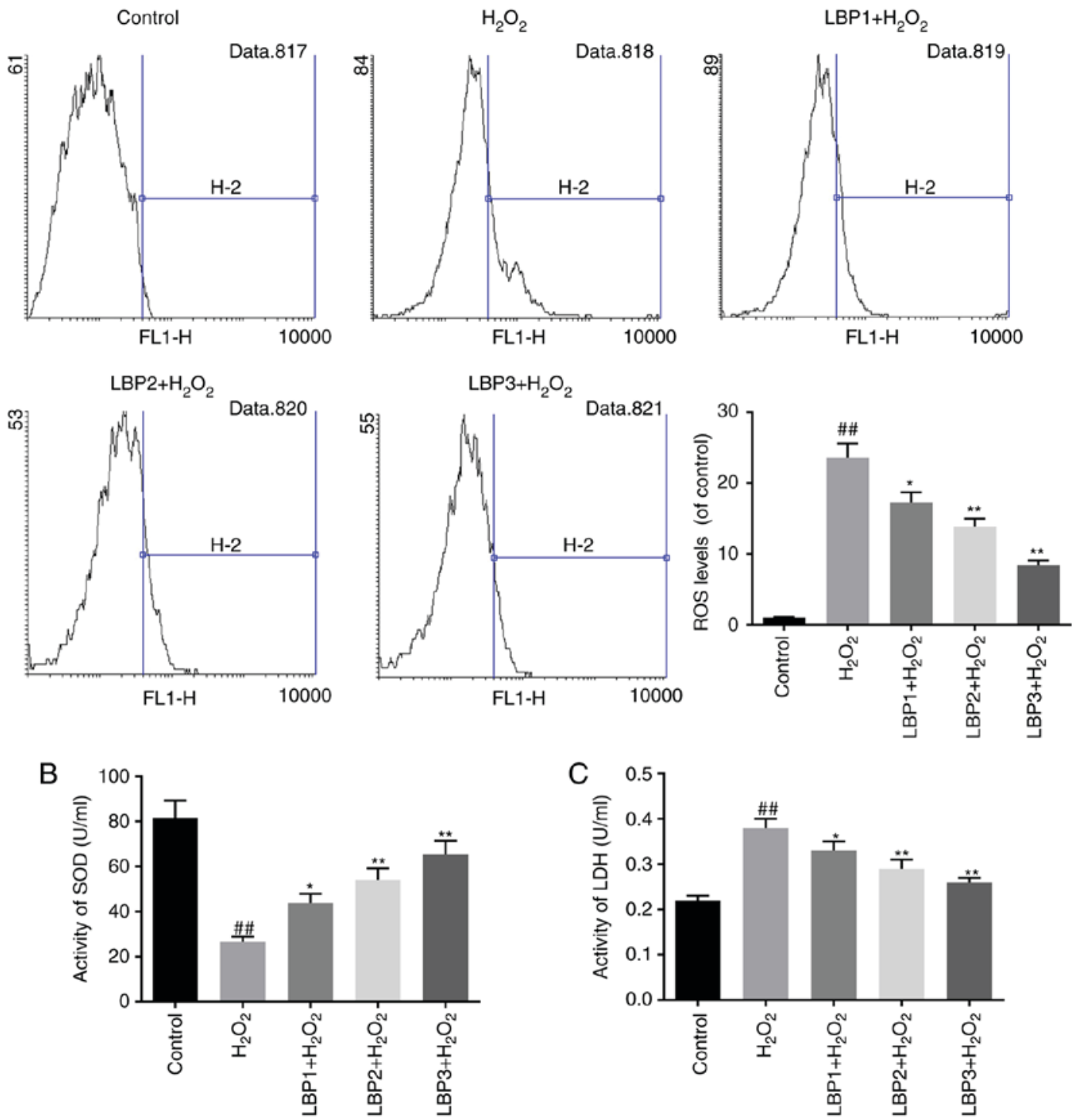

Figure 2. LBP decreases ROS and LDH levels, and increases SOD activity in HTR8/SVneo cells injured by $\mathrm{H}_{2} \mathrm{O}_{2}$. (A) Levels of ROS were detected by a 2',7'-dichlorofluorescin diacetate assay. (B) The activity of the antioxidant enzyme SOD and (C) LDH leakage in the cell supernatant was determined. ${ }^{\# \#} \mathrm{P}<0.01$ vs. control group; ${ }^{*} \mathrm{P}<0.05$ and ${ }^{* *} \mathrm{P}<0.01$ vs. $\mathrm{H}_{2} \mathrm{O}_{2}$ group. $\mathrm{H}_{2} \mathrm{O}_{2}$, hydrogen peroxide; LBP, Lycium barbarum polysaccharide; ROS, reactive oxygen species; SOD, superoxide dismutase; LDH, lactate dehydrogenase.

the $\mathrm{LBP} 1+\mathrm{H}_{2} \mathrm{O}_{2}, \mathrm{LBP} 2+\mathrm{H}_{2} \mathrm{O}_{2}$ and $\mathrm{LBP} 3+\mathrm{H}_{2} \mathrm{O}_{2}$ groups, in a dose-dependent manner, compared with the $\mathrm{H}_{2} \mathrm{O}_{2}$ group $(\mathrm{P}<0.05$; Fig. 2A).

LBP increases SOD levels and decreases $L D H$ levels in HTR8/SVneo cells injured by $\mathrm{H}_{2} \mathrm{O}_{2}$. LDH leakage reflects cytotoxicity and mitochondrial damage (26). Levels of antioxidant enzyme SOD and leaked LDH in the cell supernatant were determined by the corresponding assay kits. Decreased SOD activity and increased LDH activity was detected in the $\mathrm{H}_{2} \mathrm{O}_{2}$ group, compared with the control group $(\mathrm{P}<0.01)$. LBP increased SOD activity and decreased $\mathrm{LDH}$ activity in dose-dependent manner, compared with $\mathrm{H}_{2} \mathrm{O}_{2}$ group $(\mathrm{P}<0.05$; Fig. 2B and $\mathrm{C})$.

$L B P$ reduces the percentage of cells with $M M P$ disruption in HTR8/SVneo cells injured by $\mathrm{H}_{2} \mathrm{O}_{2}$. The percentage of cells with MMP disruption was measured by JC-1 assay. The percentage of cells with MMP disruption in the $\mathrm{H}_{2} \mathrm{O}_{2}$ group was significantly increased compared with the control group $(\mathrm{P}<0.01)$. The percentage of cells with MMP disruption in the $\mathrm{LBP} 1+\mathrm{H}_{2} \mathrm{O}_{2}, \mathrm{LBP} 2+\mathrm{H}_{2} \mathrm{O}_{2}$ and $\mathrm{LBP} 3+\mathrm{H}_{2} \mathrm{O}_{2}$ groups decreased significantly in a dose-dependent manner, when pretreated with different concentrations of LBP (100, 200 and $400 \mu \mathrm{g} / \mathrm{ml}$ ) prior to $\mathrm{H}_{2} \mathrm{O}_{2}$ injury, compared with the $\mathrm{H}_{2} \mathrm{O}_{2}$ group $(\mathrm{P}<0.05$; Fig. 3A). These results indicate that LBP may reduce MMP disruption in HTR8/SVneo cells with $\mathrm{H}_{2} \mathrm{O}_{2}$-induced injury.

LBP inhibits cell apoptosis induced by $\mathrm{H}_{2} \mathrm{O}_{2}$ in HTR8/SVneo cells. An Annexin-V/PI double-stain assay was performed to detect the apoptosis status of each group. The apoptosis rate of the $\mathrm{H}_{2} \mathrm{O}_{2}$ group significantly increased compared with control group $(\mathrm{P}<0.01)$; apoptosis in the $\mathrm{LBP} 1+\mathrm{H}_{2} \mathrm{O}_{2}$, $\mathrm{LBP} 2+\mathrm{H}_{2} \mathrm{O}_{2}$ and $\mathrm{LBP} 3+\mathrm{H}_{2} \mathrm{O}_{2}$ groups was significantly decreased in a dose-dependent manner, compared with the $\mathrm{H}_{2} \mathrm{O}_{2}$ group $(\mathrm{P}<0.05$; Fig. $3 \mathrm{~B})$. This indicated that LBP may inhibit $\mathrm{H}_{2} \mathrm{O}_{2}$-induced apoptosis in HTR8/SVneo cells. 

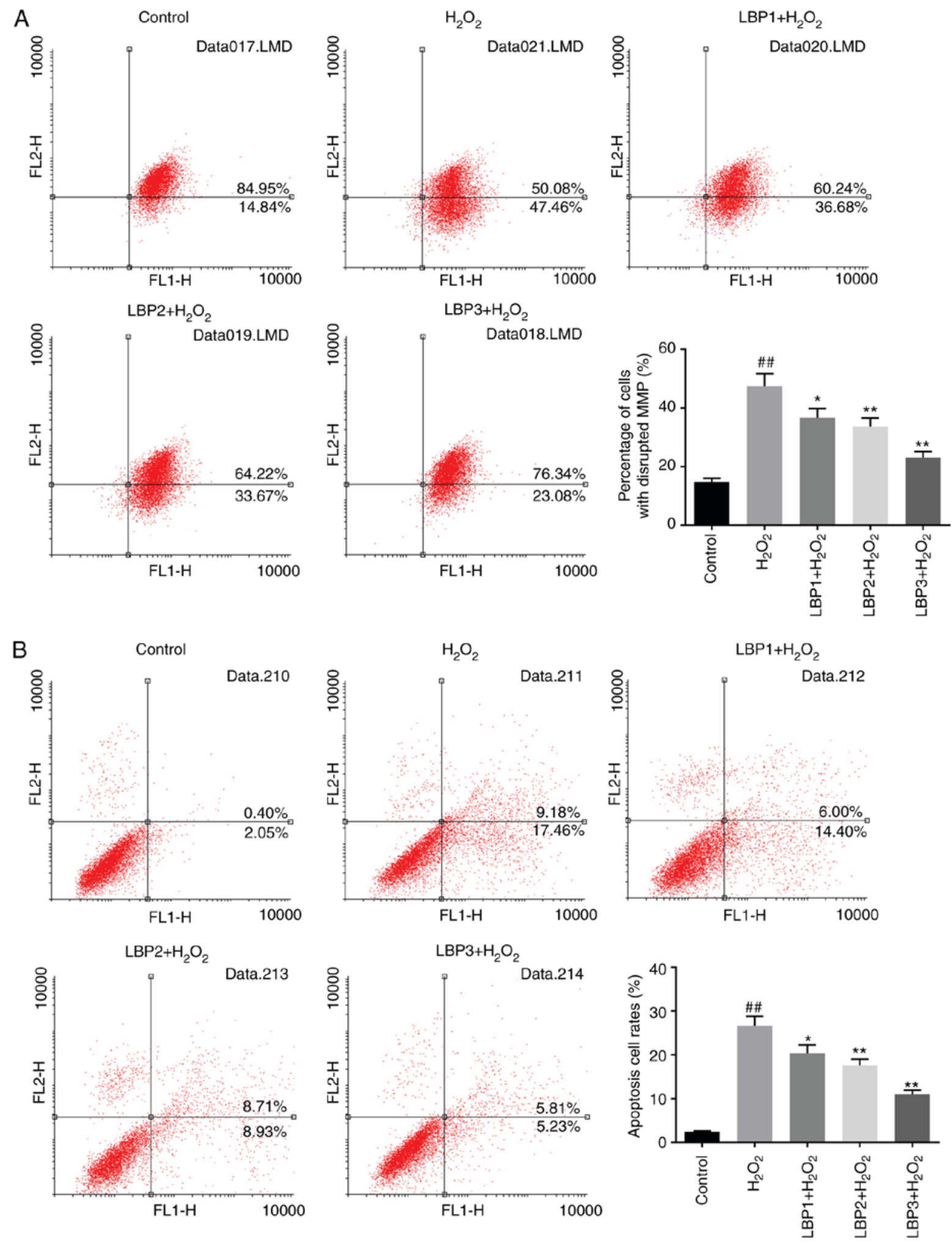

Figure 3. LBP reduces the percentage of cells with MMP disruption and inhibits cell apoptosis in HTR8/SVneo cells injured by $\mathrm{H}_{2} \mathrm{O}_{2}$. (A) MMP disruption was detected by a JC-1 assay. (B) Apoptosis was detected by an Annexin-V/propidium iodide double-stain assay and flow cytometry. ${ }^{\# \#} \mathrm{P}<0.01$ vs. control group; ${ }^{*} \mathrm{P}<0.05,{ }^{* *} \mathrm{P}<0.01$ vs. $\mathrm{H}_{2} \mathrm{O}_{2}$ group. $\mathrm{H}_{2} \mathrm{O}_{2}$, hydrogen peroxide; LBP, Lycium barbarum polysaccharide; MMP, mitochondrial membrane potential.

LBP regulates the expression of apoptosis-associated factors in HTR8/SVneo cells injured by $\mathrm{H}_{2} \mathrm{O}_{2}$. To detect whether the protective function of LBP on HTR8/SVneo cells injured by $\mathrm{H}_{2} \mathrm{O}_{2}$ was via regulation of apoptosis-associated factors, RT-qPCR (Fig. 4A) and western blot analysis (Fig. 4B and C) was performed to detect the expression of survivin, HIF1- $\alpha$, Bax and Bcl-2 in TR8/SVneo cells treated with $\mathrm{H}_{2} \mathrm{O}_{2}$ and/or LBP. The results revealed that the mRNA and protein levels of survivin, HIF1- $\alpha$ and Bcl-2 decreased significantly in $\mathrm{H}_{2} \mathrm{O}_{2}$ group compared with control group, and significantly increased in the LBP treated groups in a dose dependent manner $(\mathrm{P}<0.05)$. The mRNA and protein levels of Bax exhibited the opposite trend $(\mathrm{P}<0.05)$. 


\section{Discussion}

Pregnancy complications, including PE, cause marked damage to normal fetal development, which is associated with abnormal cytotrophoblast differentiation and invasion. As a key factor of the cellular oxidative stress cascade, $\mathrm{H}_{2} \mathrm{O}_{2}$ is considered an important component in placental oxidative ischemia/reperfusion stress. LBP has been reported to protect the testes from high-temperature injury, and improve immune ability and oxidative free radical resistance (27). However, whether LBP reduces $\mathrm{H}_{2} \mathrm{O}_{2}$-induced injury in trophoblast cells remains unclear.

LBPs are efficient free radical scavengers in vivo and may be useful in counteracting oxidative stress associated with aging $(28,29)$. Therefore, the function of LBPs on oxidative injury in trophoblast cells in vitro was investigated in the present study. At present, $\mathrm{H}_{2} \mathrm{O}_{2}$ is the most commonly used substance to construct a cell model of oxidative stress in various research fields $(30,31)$. In the present study, an oxidative injury model was established in trophoblast cells injured by $\mathrm{H}_{2} \mathrm{O}_{2}$ and the effects of LBP were examined, including those on oxidative stress, MMP and cell apoptosis. The proliferative ability of human trophoblast HTR8/SVneo cells following various treatments was evaluated with aCCK- 8 assay and revealed that proliferation was reduced by $\mathrm{H}_{2} \mathrm{O}_{2}$ and LBP reduced the damage caused by $\mathrm{H}_{2} \mathrm{O}_{2}$ in a dose-dependent manner.

Oxidative stress is the imbalance of oxidative and anti-oxidative factors in cells, resulting in more ROS production than ROS elimination, causing cell and tissue damage (32). Abundant ROS accumulate when the placenta is under conditions of ischemia hypoxia, and trophoblast cells suffer from oxidative stress when pregnancy complications exist (33-36). The present study demonstrated that $\mathrm{H}_{2} \mathrm{O}_{2}$ treatment of cells resulted in abundant ROS accumulation in trophoblast cells, and LBP decreased the levels of ROS and oxidative stress induced by $\mathrm{H}_{2} \mathrm{O}_{2}$. Following this, the potential effect of LBP on antioxidant levels in $\mathrm{H}_{2} \mathrm{O}_{2}$ injured trophoblast HTR8/SVneo cells was also investigated. SOD is the most important antioxidant in the defense system of antioxidative injury (37). The latest LBP chemical component analysis demonstrated that all glycopeptides in LBP act as the eliminators of lipid peroxide active components (38-40). Thus, it was speculated that as an anti-oxidant, LBP may decrease trophoblast cell injury induced by oxygen free radicals and protect cell development and differentiation. The results of the present study demonstrated that LBP significantly increased SOD activity and reduced ROS levels simultaneously, to protect cells from oxidative injury. Disruption of the cell membrane induced by oxidative stress or apoptosis may mediate the release of enzymes from the cytoplasm into the culture media, including LDH, which is relatively stable. By detecting the amount of LDH leakage into culture media, the cytomembrane integrity was measured. The results indicated that LDH leakage was attenuated by LBP treatment in $\mathrm{H}_{2} \mathrm{O}_{2}$ injured trophoblast cells.

Oxidative stress is one of the main causes of cell apoptosis, through the mitochondria-dependent or independent pathways (41). Mitochondrial dysfunction caused by damage to structural integrity induces oxidative stress and the release of ROS (42). In addition, the apoptosis rates may reflect the degree of oxidative stress (43-45). The present research demonstrated an increased percentage of cells with MMP disruption and
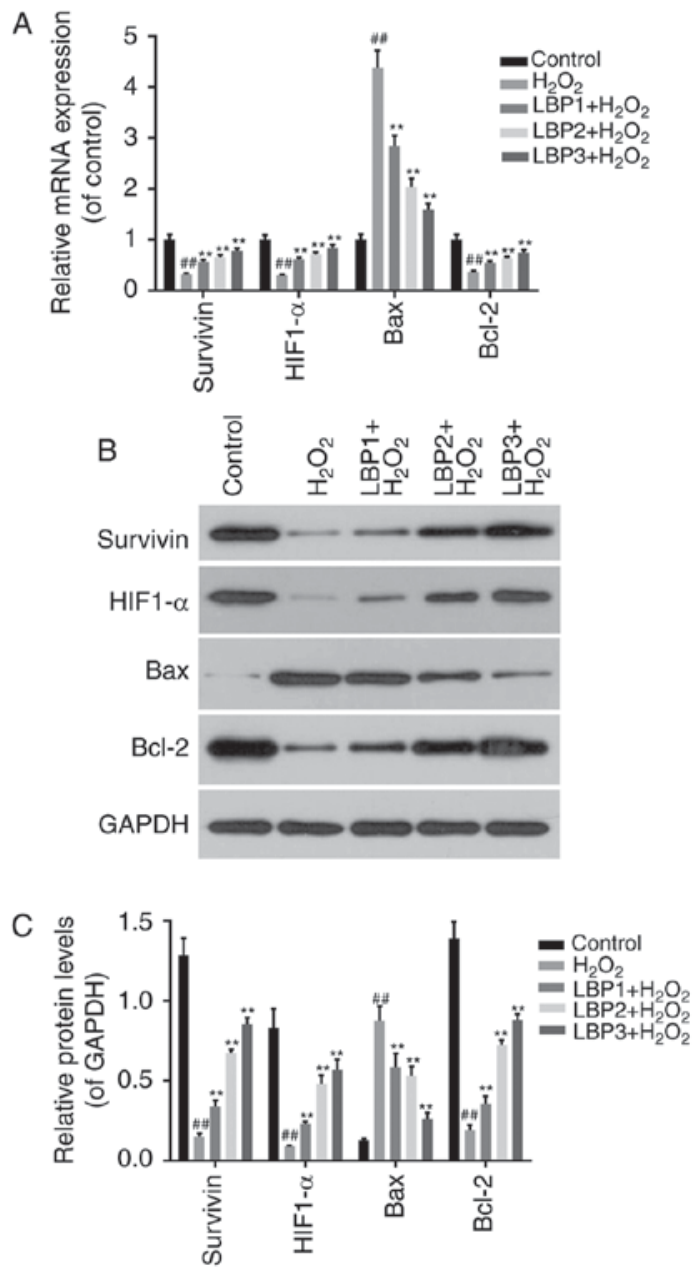

Figure 4. LBP regulates the expression of apoptosis-associated factors in HTR8/SVneo cells injured by $\mathrm{H}_{2} \mathrm{O}_{2}$. (A) Reverse transcription-quantitative polymerase chain reaction was performed to detect the mRNA levels of survivin, HIF1- $\alpha$, Bax and Bcl-2 in TR8/SVneo cells treated with $\mathrm{H}_{2} \mathrm{O}_{2}$ and/or LBP. (B) Western blot analysis was performed to detect the protein levels of survivin, HIF1- $\alpha$, Bax and Bcl-2 in TR8/SVneo cells treated with $\mathrm{H}_{2} \mathrm{O}_{2}$ and/or LBP. (C) Relative protein levels were determined by densitometric analysis. ${ }^{\# \#} \mathrm{P}<0.01$ vs. control group; ${ }^{*} \mathrm{P}<0.05,{ }^{* * *} \mathrm{P}<0.01$ vs. $\mathrm{H}_{2} \mathrm{O}_{2}$ group. $\mathrm{H}_{2} \mathrm{O}_{2}$, hydrogen peroxide; LBP, Lycium barbarum polysaccharide; HIF1- $\alpha$, hypoxia inducible factor 1- $\alpha$; Bax, Bax, Bcl-2 associated $\mathrm{X}$ apoptosis regulator; Bcl-2, $\mathrm{Bcl}-2$ apoptosis regulator.

apoptosis in trophoblast cells injured by $\mathrm{H}_{2} \mathrm{O}_{2}$, whereas LBP could markedly alleviate these effects. Furthermore, it was revealed that the function of LBP in protecting trophoblast cells from $\mathrm{H}_{2} \mathrm{O}_{2}$-induced injury may be via regulation of apoptosis-associated factors, including survivin, HIF1- $\alpha$, Bax and Bcl-2.

Survivin is an important member of the inhibitor of apoptosis protein family that regulates apoptosis and cell division (46). Previous research has demonstrated that the expression of survivin in embryonic development promotes tissue stability and differentiation $(47,48)$. The inhibition of survivin expression in the early stage of embryonic development results in embryonic deformities (49). HIF1- $\alpha$ is highly expressed in anaerobic conditions, and promotes cell proliferation and tumor angiogenesis in cancer $(50,51)$. Previous studies demonstrated that HIF1- $\alpha$ overexpression is associated with tumor aggressiveness in human neoplasms $(52,53)$. HIF1- $\alpha$ knockdown promotes cell apoptosis 
by downregulating surviving, and upregulating caspase-3 and other apoptosis-promoting factors (54). Bcl-2 family members directly regulate death signals, or act indirectly through the intrinsic pathways of apoptosis, including regulation of pro-apoptotic factor release from the mitochondria. Aberrant excess expression of Bcl-2 inhibits cell apoptosis and induces tumor development, including in gastric, lung, papillary thyroid and ovarian cancer (55-58). Bax interacts with Bcl-2 to suppress its apoptosis-inhibiting effects. The data of the present study indicated that $\mathrm{H}_{2} \mathrm{O}_{2}$ may suppress the mRNA and protein expression of survivin, HIF1- $\alpha$ and Bcl-2, and facilitate Bax expression to promote apoptosis and oxidative stress. LBP pre-treatment promoted the expression of survivin, HIF1- $\alpha$ and Bcl-2, and decreased Bax expression to inhibit apoptosis and oxidative stress. Taken together, the results of the present study suggest that LBP alleviated $\mathrm{H}_{2} \mathrm{O}_{2}$-induced oxidative stress through altering MMP, inhibiting cell apoptosis and regulating the expression of apoptosis-associated factors in HTR8/SVneo cells.

In summary, an $\mathrm{H}_{2} \mathrm{O}_{2}$-injured HTR8/SVneo trophoblast cell model was constructed and LBP was demonstrated to reduce oxidative stress and apoptosis via regulating the expression of apoptosis-associated factors. Future research should focus on elucidating the mechanism of LBP in oxidative stress alleviation in trophoblast cells. Increased trophoblast cell protection from oxidative stress and apoptosis in pregnancy may provide improved treatment outcomes for individuals with pregnancy complications. In the future, the authors of the present study will examine the effects of LBP from a mechanistic view, in order to identify the receptors and downstream signals involved.

\section{Acknowledgements}

Not applicable.

\section{Funding}

Not applicable.

\section{Availability of data and materials}

All data generated or analyzed during this study are included in this published article.

\section{Authors' contributions}

JL designed the study; JL and ZD performed the flow cytometry to investigate the role of LBP on ROS, mitochondria and apoptosis regulation; YY detected cell viability; BM and YW did the RT-qPCR and western blotting assays; XX analyzed and interpreted all the experiments' data, drafted the manuscript and revised it.

\section{Ethics approval and consent to participate}

Not applicable.

\section{Patient consent for publication}

Not applicable.

\section{Competing interests}

The authors declare that they have no competing interests.

\section{References}

1. Kim YM, Chaiworapongsa T, Gomez R, Bujold E, Yoon BH, Rotmensch S, Thaler HT and Romero R: Failure of physiologic transformation of the spiral arteries in the placental bed in preterm premature rupture of membranes. Am J Obstet Gynecol 187: 1137-1142, 2002.

2. Pardi G, Marconi AM and Cetin I: Pathophysiology of intrauterine growth retardation: Role of the placenta. Acta Paediatr Suppl 423: 170-172, 1997.

3. Hauspurg A, Ying W, Hubel CA, Michos ED and Ouyang P: Adverse pregnancy outcomes and future maternal cardiovascular disease. Clin Cardiol 41: 239-246, 2018.

4. Hannan NJ, Binder NK, Beard S, Nguyen TV, Kaitu'u-Lino TJ and Tong S: Melatonin enhances antioxidant molecules in the placenta, reduces secretion of soluble fms-like tyrosine kinase 1 (sFLT) from primary trophoblast but does not rescue endothelial dysfunction: An evaluation of its potential to treat preeclampsia. PLoS One 13: e0187082, 2018.

5. Wan J, Hu Z, Zeng K, Yin Y, Zhao M, Chen M and Chen Q: The reduction in circulating levels of estrogen and progesterone in women with preeclampsia. Pregnancy Hypertens 11: 18-25, 2018.

6. Nagai R, Watanabe K, Wakatsuki A, Hamada F, Shinohara K, Hayashi Y, Imamura R and Fukaya T: Melatonin preserves fetal growth in rats by protecting against ischemia/reperfusion-induced oxidative/nitrosative mitochondrial damage in the placenta. J Pineal Res 45: 271-276, 2008.

7. Okatani Y, Wakatsuki A, Shinohara K, Taniguchi K and Fukaya T: Melatonin protects against oxidative mitochondrial damage induced in rat placenta by ischemia and reperfusion. J Pineal Res 31: 173-178, 2001.

8. Aris A, Benali S, Ouellet A, Moutquin JM and Leblanc S: Potential biomarkers of preeclampsia: Inverse correlation between hydrogen peroxide and nitric oxide early in maternal circulation and at term in placenta of women with preeclampsia. Placenta 30: 342-347, 2009.

9. Straszewski-Chavez SL, Abrahams VM and Mor G: The role of apoptosis in the regulation of trophoblast survival and differentiation during pregnancy. Endocr Rev 26: 877-897, 2005.

10. Fukushima K, Miyamoto S, Tsukimori K, Kobayashi H, Seki H, Takeda S, Kensuke E, Ohtani K, Shibuya M and Nakano H: Tumor necrosis factor and vascular endothelial growth factor induce endothelial integrin repertories, regulating endovascular differentiation and apoptosis in a human extravillous trophoblast cell line. Biol Reprod 73: 172-179, 2005.

11. Huppertz B, Frank HG, Kingdom JC, Reister F and Kaufmann P: Villous cytotrophoblast regulation of the syncytial apoptotic cascade in the human placenta. Histochem Cell Biol 110: 495-508, 1998.

12. Lewis MP, Clements M, Takeda S, Kirby PL, Seki H,Lonsdale LB, Sullivan MH, Elder MG and White JO: Partial characterization of an immortalized human trophoblast cell-line, TCL-1, which possesses a CSF-1 autocrine loop. Placenta 17: 137-146, 1996.

13. Smith SC, Baker PN and Symonds EM: Increased placental apoptosis in intrauterine growth restriction. Am J Obstet Gynecol 177: 1395-1401, 1997.

14. Crocker IP, Cooper S, Ong SC and Baker PN: Differences in apoptotic susceptibility of cytotrophoblasts and syncytiotrophoblasts in normal pregnancy to those complicated with preeclampsia and intrauterine growth restriction. Am J Pathol 162: 637-643, 2003.

15. Ishihara N, Matsuo H, Murakoshi H, Laoag-Fernandez JB, Samoto T and Maruo T: Increased apoptosis in the syncytiotrophoblast in human term placentas complicated by either preeclampsia or intrauterine growth retardation. Am J Obstet Gynecol 186: 158-166, 2002.

16. DiFederico E, Genbacev $\mathrm{O}$ and Fisher SJ: Preeclampsia is associated with widespread apoptosis of placental cytotrophoblasts within the uterine wall. Am J Pathol 155: 293-301, 1999.

17. Moindjie H, Santos ED, Gouesse RJ, Swierkowski-Blanchard N, Serazin V, Barnea ER, Vialard F and Dieudonne MN: Preimplantation factor is an anti-apoptotic effector in human trophoblasts involving p53 signaling pathway. Cell Death Dis 7: e2504, 2016. 
18. Wang Z, Liu Y, Sun Y, Mou Q, Wang B, Zhang Y and Huang L: Structural characterization of LbGp1 from the fruits of Lycium barbarum L. Food Chem 159: 137-142, 2014.

19. Varoni MV, Gadau SD, Pasciu V, Baralla E, Serra E, Palomba D and Demontis MP: Investigation of the effects of Lycium barbarum polysaccharides against cadmium induced damage in testis. Exp Mol Pathol 103: 26-32, 2017.

20. Po KK, Leung JW, Chan JN, Fung TK, Sánchez-Vidaña DI, Sin EL, So KF, Lau BW and Siu AM: Protective effect of Lycium Barbarum polysaccharides on dextromethorphan-induced mood impairment and neurogenesis suppression. Brain Res Bull 134: 10-17, 2017.

21. Liu WJ, Jiang HF, Rehman FU, Zhang JW, Chang Y, Jing L and Zhang JZ: Lycium barbarum polysaccharides decrease hyperglycemia-aggravated ischemic brain injury through maintaining mitochondrial fission and fusion balance. Int J Biol Sci 13: 901-910, 2017.

22. Liu L, Lao W, Ji QS, Yang ZH, Yu GC and Zhong JX: Lycium barbarum polysaccharides protected human retinal pigment epithelial cells against oxidative stress-induced apoptosis. Int J Ophthalmol 8: 11-16, 2015.

23. Zhang XJ, Yu HY, Cai YJ and Ke M: Lycium barbarum polysaccharides inhibit proliferation and migration of bladder cancer cell lines BIU87 by suppressing Pi3K/AKT pathway. Oncotarget 8 : 5936-5942, 2017

24. Tian JY, Chen WW, Cui J, Wang H, Chao C, Lu ZY and Bi YY: Effect of Lycium bararum polysaccharides on methylmercury-induced abnormal differentiation of hippocampal stem cells. Exp Ther Med 12: 683-689, 2016.

25. Livak KJ and Schmittgen TD: Analysis of relative gene expression data using real-time quantitative PCR and the 2(-Delta Delta C(T)) method. Methods 25: 402-408, 2001

26. Datta $S$ and Chakrabarti N: Age related rise in lactate and its correlation with lactate dehydrogenase (LDH) status in post-mitochondrial fractions isolated from different regions of brain in mice. Neurochem Int 118: 23-33, 2018.

27. Shan T, Shan T, Liu F, Zheng H and Li G: Effects of Lycium barbarum polysaccharides on the damage to human endometrial stromal cells induced by hydrogen peroxide. Mol Med Rep 15: 879-884, 2017.

28. Gao Y, Wei Y, Wang Y, Gao F and Chen Z: Lycium barbarum: A traditional chinese herb and a promising anti-aging agent. Aging Dis 8: 778-791, 2017.

29. Lin CL, Wang CC, Chang SC, Inbaraj BS and Chen BH: Antioxidative activity of polysaccharide fractions isolated from Lycium barbarum Linnaeus. Int J Biol Macromol45: 146-151,2009.

30. Bittner L, Wyck S, Herrera C, Siuda M, Wrenzycki C, van Loon B and Bollwein $\mathrm{H}$ : Negative effects of oxidative stress in bovine spermatozoa on in vitro development and DNA integrity of embryos. Reprod Fertil Dev: May 1, 2018 (Epub ahead of print).

31. Che X,Zhao Q and Li D: Expression of thioredoxin-2 in human lens epithelial cells with oxidative damage and its significance. Zhong Nan Da Xue Xue Bao Yi Xue Ban 43: 253-259, 2018 (In Chinese).

32. Kupsco A and Schlenk D: Oxidative stress, unfolded protein response, and apoptosis in developmental toxicity. Int Rev Cell Mol Biol 317: 1-66, 2015

33. Poston L, Igosheva N, Mistry HD, Seed PT, Shennan AH, Rana S Karumanchi SA and Chappell LC: Role of oxidative stress and antioxidant supplementation in pregnancy disorders. Am J Clin Nutr 94 (6 Suppl): 1980S-1985S, 2011.

34. Deepa D, Jayakumari N and Thomas SV: Oxidative stress is increased in women with epilepsy: Is it a potential mechanism of anti-epileptic drug-induced teratogenesis? Ann Indian Acad Neurol 15: 281-286, 2012

35. Kovacic P and Somanathan R: Mechanism of teratogenesis: Electron transfer, reactive oxygen species, and antioxidants. Birth Defects Res C Embryo Today 78: 308-325, 2006.

36. Burton GJ and Jauniaux E: Placental oxidative stress: From miscarriage to preeclampsia. J Soc Gynecol Investig 11: 342-352, 2004.

37. Su Y, Han W and Cao Y: Association between activities of SOD, MDA and Na+-K+-ATPase in peripheral blood of patients with acute myocardial infarction and the complication of varying degrees of arrhythmia. Hellenic J Cardiol: Apr 24, 2018 (Epub ahead of print).

38. Schoppet M, Tailhades J, Kulkarni K and Cryle MJ: Precursor Manipulation in Glycopeptide Antibiotic Biosynthesis: Are $\beta$-Amino Acids Compatible with the Oxidative Cyclization Cascade? J Org Chem: Apr 30, 2018 (Epub ahead of print).

39. Chen L, Li W, Qi D and Wang D: Lycium barbarum polysaccharide protects against LPS-induced ARDS by inhibiting apoptosis, oxidative stress, and inflammation in pulmonary endothelial cells. Free Radic Res 52: 480-490, 2018
40. Varoni MV, Pasciu V, Gadau SD, Baralla E, Serra E, Palomba D and Demontis MP: Possible antioxidant effect of Lycium barbarum polysaccharides on hepatic cadmium-induced oxidative stress in rats. Environ Sci Pollut Res Int 24: 2946-2955, 2017.

41. Sinha K, Das J, Pal PB and Sil PC: Oxidative stress: The mitochondria-dependent and mitochondria-independent pathways of apoptosis. Arch Toxicol 87: 1157-1180, 2013.

42. Chen S, Lv X, Hu B, Zhao L, Li S, Li Z, Qing X, Liu H, Xu J and Shao Z: Critical contribution of RIPK1 mediated mitochondrial dysfunction and oxidative stress to compression-induced rat nucleus pulposus cells necroptosis and apoptosis. Apoptosis: Apr 28, 2018 (Epub ahead of print).

43. Ahmadian E, Khosroushahi AY, Eftekhari A, Farajnia S, Babaei $\mathrm{H}$ and Eghbal MA: Novel angiotensin receptor blocker, azilsartan induces oxidative stress and NFkB-mediated apoptosis in hepatocellular carcinoma cell line HepG2. Biomed Pharmacother 99: 939-946, 2018.

44. Liang J, Wu S, Xie W and He H: Ketamine ameliorates oxidative stress-induced apoptosis in experimental traumatic brain injury via the Nrf2 pathway. Drug Des Devel Ther 12: 845-853, 2018.

45. Namazi Sarvestani N, Saberi Firouzi S, Falak R, Karimi MY, Davoodzadeh Gholami M, Rangbar A and Hosseini A: Phosphodiesterase 4 and 7 inhibitors produce protective effects against high glucose-induced neurotoxicity in PC12 cells via modulation of the oxidative stress, apoptosis and inflammation pathways. Metab Brain Dis: Apr 30, 2018 (Epub ahead of print).

46. Zhang Z, Wang H, Jin Z, Cai X, Gao N, Cui X, Liu P, Zhang J, Yang $S$ and Yang X: Downregulation of survivin regulates adult hippocampal neurogenesis and apoptosis, and inhibits spatial learning and memory following traumatic brain injury. Neuroscience 300: 219-228, 2015.

47. Ambrosini G, Adida C and Altieri DC: A novel anti-apoptosis gene, survivin, expressed in cancer and lymphoma. Nat Med 3: 917-921, 1997.

48. Kawasaki H, Altieri DC, Lu CD, Toyoda M, Tenjo T and Tanigawa N: Inhibition of apoptosis by survivin predicts shorter survival rates in colorectal cancer.Cancer Res 58: 5071-5074,1998.

49. Adida C, Crotty PL, McGrath J, Berrebi D, Diebold J and Altieri DC: Developmentally regulated expression of the novel cancer anti-apoptosis gene survivin in human and mouse differentiation. Am J Pathol 152: 43-49, 1998.

50. Magnon C, Opolon P, Ricard M, Connault E, Ardouin P, Galaup A, Métivier D, Bidart JM, Germain S, Perricaudet M and Schlumberger M: Radiation and inhibition of angiogenesis by canstatin synergize to induce HIF-1alpha-mediated tumor apoptotic switch. J Clin Invest 117: 1844-1855, 2007.

51. Fujiwara S, Nakagawa K, Harada H, Nagato S, Furukawa K, Teraoka M, Seno T, Oka K, Iwata S and Ohnishi T: Silencing hypoxia-inducible factor-1alpha inhibits cell migration and invasion under hypoxic environment in malignant gliomas. Int $\mathbf{J}$ Oncol 30: 793-802, 2007.

52. Unruh A, Ressel A, Mohamed HG, Johnson RS, Nadrowitz R, Richter E, Katschinski DM and Wenger RH: The hypoxia-inducible factor-1 alpha is a negative factor for tumor therapy. Oncogene 22: 3213-3220, 2003.

53. Zagzag D, Zhong H, Scalzitti JM, Laughner E, Simons JW and Semenza GL: Expression of hypoxia-inducible factor 1alpha in brain tumors: Association with angiogenesis, invasion, and progression. Cancer 88: 2606-2618, 2000.

54. Li X, Liu X, Xu Y, Liu J, Xie M, Ni W and Chen S: KLF5 promotes hypoxia-induced survival and inhibits apoptosis in non-small cell lung cancer cells via HIF-1 $\alpha$. Int J Oncol 45: 1507-1514, 2014.

55. Mitselou A, Peschos D, Dallas P, Charalabopoulos K, Agnantis NJ and Vougiouklakis T: Immunohistochemical analysis of expression of bcl-2 protein in papillary carcinomas and papillary microcarcinomas of the thyroid gland. Exp Oncol 26: 282-286, 2004.

56. Basolo F, Pollina L, Fontanini G, Fiore L, Pacini F and Baldanzi A: Apoptosis and proliferation in thyroid carcinoma: Correlation with bcl-2 and p53 protein expression. Br J Cancer 75: 537-541, 1997.

57. Yoo NJ, Kim MS and Lee SH: Expression and mutation analyses of Fas, FLIP and $\mathrm{Bcl}-2$ in granulosa cell tumor of ovary. Tumori 98: 118e-121e, 2012.

58. Yildirim M, Suren D, Goktas S, Dilli UD, Kaya C, Copuroglu R, Yildiz $\mathrm{M}$ and Sezer C: The predictive role of Bcl-2 expression in operable locally advanced or metastatic gastric carcinoma. J BUON 17: 106-109, 2012.

This work is licensed under a Creative Commons Attribution-NonCommercial-NoDerivatives 4.0 International (CC BY-NC-ND 4.0) License. 